\title{
Virtual Colonies Between Teacher with Student
}

\author{
Susilaningsih \\ Malang State University, Malang, Indonesia \\ Corresponding e-mail: Susiladjihad@gmail.com
}

\begin{abstract}
Development of virtual colonies with teacher and student entities needs to be done in cyberspace. Virtual colonies provide simplification and flexibility that is increasingly becoming a trend in society. More online systems are in demand by the public. The colony system begins with e-mail, followed by forum technology on the web blog, thus enabling the public to convey information as learning content, through the flexibility of the web and social media. The use of the online community system proves the existence of colonies and networks. The establishment of colonies as the implementation of on-line technology will lead to colonies that have learning content. Colonies serves to provide a special space on learning to inform and communicate in the learning corridor.
\end{abstract}

Keywords: Colonies, Entities, Teachers, Students, On-line

\section{INTRODUCTION}

The use of the virtual world with on-line technology begins to shift from lifestyle to a need. On-line technology in Internet applications can begin to realize can store information and information that can be accessed more easily, anytime and anywhere, then the use of the Internet becomes a necessity. Not only that, Internet users can communicate with other parties in a very easy way through the facilities available on the Internet.

The positive paradigm built by education providers, has led to the alignment of the use of on-line technology by utilizing the internet. The educational providers have thought that the use of the Internet can encourage students to be more active learners, it is possible that there are various variations that can be done in the learning and teaching process, the acquisition of multiple skills and the achievement of efficiency. From various experiences and also from the various information available in the literature provide guidance on the benefits of using the Internet, especially in open and distance education (Elangoan, 1999; Mulvihil, 1997; Utarini, 1997), among others, can be mentioned as follows: 1) Availability of e-Moderating facilities where teachers and students can communicate easily through Internet facilities regularly or whenever communication activities are conducted without being limited by distance, place and time. 2) Teachers and students can use instructional materials or structured and scheduled learning instructions through the Internet, so that they can judge each other to the extent to which the teaching materials are learned; 3) Students can learn or review teaching materials anytime and anywhere if needed considering the teaching materials are stored on the computer. 4) If the student requires additional information related to the material he / she studied, he or she can access the Internet more easily. 5) Both teachers and students can conduct discussions through the Internet that can be followed by a large number of participants, thus adding knowledge and broader insights. 6) The changing role of the student from the normally passive becomes active; 7) Relatively more efficient. For example, for those who live far from conventional colleges or schools, for those who are busy working, for those who are on duty aboard, abroad, etc.

Teachers and students are potential entities to build a colony. Good management of colonies of teachers and students will provide a positive reinforcement of paradigms built by education providers and are expected to reduce the adverse impacts of Internet utilization. People are beginning to think about how to find secure social networks, nonprovocative blogs, morals and so on, solely to save their sons and daughters and be able to provide a positive internet activity. 


\section{METHOD}

The Web-Based Colony Application Development Model is Shivers and Rasmussen selected based on conformity to the needs of developmental characteristics. The need for learning development is the development of teacher and student colonies with the main characteristics of On-line web-based activities. Overall Shivers and Rasmussen models are development methods that have dominant characteristics in web-based development.

Method of Design Development Colonies of teachers and students Model DavidsonShivers and Rasmussen have development phases including: 1). Analysis; 2). Evaluation Plan 3) Concurrent Phases covering design, system development, testing and Implementation and Formative evaluation. This phase can be done many times until an unspecified time limit; 4). Comprehensive Implementation; 5). A thorough review.

Methods Application Development Management Colonies of teachers and students Model Shivers and Rasmussen can be described as a development activity consisting of activities divided into 2 years of development stage. The development stage is as follows:

\subsection{Analysis}

The process of analysis is illustrated as having an impact on the design process alone and does not affect the Design Concurrently as a whole. The process of analysis and design is not a sequential process but the analysis process gives effect to the design process. However, processes in the Design Environment are not directly affected. The analysis process includes two fese namely the analysis of problem of colony formation of teacher and student and analysis of component of colony formation of teacher and student. The result of both phases is the documentation of the early stage design development. The design documentation will be a policy maker in the development of Web-based teacher and student colony applications. The design documentation is a rational Design of the establishment of teacher and student colonies and initial justification of the initial Application Design of teachers and student Colonies. The justification in question is a justification for the sustainability of the next process. Problem Analysis is an investigative activity on the performance of the problem and not only find the problem but also the search for problem solving. Analysis of the learning component is a situational analysis

\subsection{Evaluation design}

The web developer, in this case the researcher, determines the formative evaluation instrument for the application of the teacher and student colony management system at the same time. The design process of evaluation has an impact on the process of formative evaluation. Evaluation planning is the planning stage of matters related to the evaluation of evaluation and formative. Instrument determination includes effectiveness (effectiveness), efficiency (efficiency) and appeal (appeal). Determination of Expert Team and Practitioner. Determination of sample of teachers and students as web users.

\subsection{Activity planning}

Activity planning stage in the drawing process is not illustrated because it is only the stage that started the design process. Activity planning stage is not a development process but a step that must be passed. The developers of Colony Design teachers and students need to do management development needs. Things to do include identifying the researcher's need for the development of learning content.

\subsection{Design Process}

In the design process carried out the investigation of the object specification, draft assessment, or better known as the Task Objective Assessment Item Blueprint (TOAB). The first blueprint grouping is an example of assessment, step of the learning process, user data, learning model and learning strategy. The second Blueprint is the learning orientation, the delivery model and the learning content, the measurement of the learning process, the conclusion and the cover

\subsection{Development Process}

Development process cannot be separated from the testing process, formative evaluation and design process. This process is the activity of the formation of learning products. To be a product that is considered good, the 
development process is done more than once. This means that other processes also experience repetition.

\subsection{Formative}

Formative evaluation is an evaluation activity conditioned on the start time of designing up to the time of learning development of a web-based blended model. Formative evaluation is intended to look at the design of teacher and student colonies against weaknesses and is used to revise the design of colonies of teachers and students.

\section{RESULTS AND DISCUSSION}

The formation of colonies of teachers and students is an application that utilizes the progress of science and technology (IPTEK) so rapidly, especially information and communication technology ( Information, Communication and Technology or ICT). The progress of science and technology especially ICT in tune with the progress of economic development in a country. Although it is realized that the utilization of ICT science and technology is still dominated by information technology users mostly in developed countries (Soekartawi, 2002a, c).

The development of ICT science and technology to date has reached the technology of sending information through messages recorded on cassette tape recorders or videotapes; We can communicate by phone anywhere, in the office, in the car, in the bathroom or elsewhere because of a hand phone, a tiny phone that can be taken anywhere. We can search the various information we want through the information technology stored on the Internet computer, which is broadcast through television, radio or in other media. In other words, information is everywhere around us.

The technology of the colony that is built includes 4 technological concepts, namely: 1) Audio Information Technologies (radio, audio tape, voice mail telephone), 2) Video Information Technologies (video tape, video text, video messaging), 3) Data Information Technologies (bulletin Board, Internet, e-mail, tele collaboration); and 4) Combination of written technology (audio / data, video / data, audio / video).

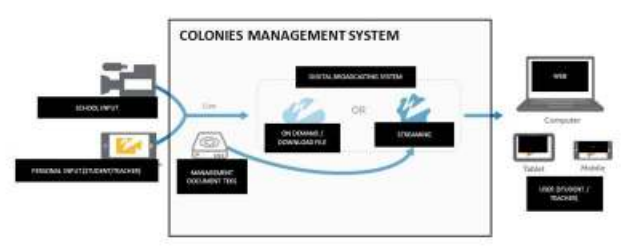

Figure 1. Colonies Management System

The cornerstone of development is a web technology that has an e-Learning paradigm. Pradigma is a relatively new information technology in Indonesia. E-Learning consists of two parts, namely ' $\mathrm{e}^{-}$ which stands for 'electronics' and learning. So e-Learning means learning by using the help of electronic devices, especially computer devices. Therefore, e-Learning is often referred to as an 'on-line course'. Thus, e-Learning or learning through online is learning that its implementation is supported by technology services such as telephone, audio, video tape,

Development is an extension of eLearning utilization . Specification development especially on the use of Internet for learning activities that is virtual library or virtual school. But the technology recognized the colony is not entirely new. However, it must be admitted that the utilization of e-Learning in Indonesia is still lagging when compared to neighboring countries such as Malaysia, Thailand, Philippines and Singapore. This can be seen from the data of Internet users where the largest Internet user is in developed countries.

\section{DISCUSSION}

The establishment of colonies with teachers and student entities can not be released with the role of the Internet. According to Williams (1999) the Internet is 'a large collection of computers in networks that are tied together so that many users can share their vast resources'. So the Internet is basically a collection of information available on computers that can be accessed because of the network available on the computer. Therefore, it can be understood that e-Learning can be implemented because of this Internet service. E-Learning is often referred to as online course because the application utilizes Internet services.

In the last ten years, the growth of Internet users in Indonesia is also not less rapid when compared with users abroad. According to Telcordia Internet Sizer records July 4, 2002, 
Indonesia is among the top 10 countries of Internet users whose numbers are increasing rapidly. These ten countries are Brazil, Chile, India, Indonesia, Malaysia, Mexico, Portugal, Spain, Thailand, and Ukraine. The rapid growth of Internet users is certainly related to the views of people who see using the Internet is a necessity to support their daily activities. In the meantime, the Indocisc (2002) record shows that the number of Internet Service Providers (ISPs) in Indonesia that operate is over 150 and they are registered and have an operating license from the DGPT. If in 2000 the number of Internet users in Indonesia is estimated to be around 2 million people, then the end of 2001 the number is expected to double and now estimated to reach about 7 million people. Not only that, the number of domains that use 'dot id' or '.id' rose drastically. Indocisc (2002) records show that the number of domains in Indonesia in 1995 amounted to only 87 and in March 2001, the number increased and reached 9,785 or increased by 112 times for 7 years or increased by 16 -fold for each year or up about $133 \%$ Every month. Then the end of 2001 the number is expected to double and now estimated to reach about 7 million people. Not only that, the number of domains that use 'dot id' or '.id' rose drastically. Indocisc (2002) records show that the number of domains in Indonesia in 1995 amounted to only 87 and in March 2001, the number increased and reached 9,785 or increased by 112 times for 7 years or increased by 16 -fold for each year or up about $133 \%$ Every month. Then the end of 2001 the number is expected to double and now estimated to reach about 7 million people. Not only that, the number of domains that use 'dot id' or '.id'rose drastically. Indocisc (2002) records show that the number of domains in Indonesia in 1995 amounted to only 87 and in March 2001, the number increased and reached 9,785 or increased by 112 times for 7 years or increased by 16 -fold for each year or up about $133 \%$ Every month.

Although the number of Internet users and the number of Internet domains in Indonesia rose sharply, but the use of the Internet for learning is still limited. Whereas in neighboring countries such as Thailand and Malaysia, Internet and ICT facilities have been utilized in high school schools. This means that each school has been provided computer facilities. In Malaysia known as SMART School. This school cooperates with Telekom Malaysia where in its implementation not only schools utilize IT and Internet for the learning and teaching process but also for the purpose of efficiency management of education management. Officials in charge of education at the district level,

Utilization of the Internet in Indonesia at the ' just starting' stage. The actual use of the Internet for e-Learning in Indonesia can be improved if facilities that support it adequate, both facilities in the form of infrastructure and facilities that are policy. This is not only supported by the data as presented above, but also the increasing number of Internet cafes ( Internet Kiosk) that appear in various corners in Indonesia.

Internet users not only from among students and students, but also from other communities. It can be used as an indication that the Internet is necessary to help smooth the work or tasks of Internet users. But due to various limitations, the facility of Internet development in Indonesia has not been as expected. It should be acknowledged, however, that the government has facilitated the growth and development of the Internet in Indonesia, by establishing various facilities, whether it be telephone networks, electricity and other facilities. Information and Technology Information or Technology Information Kiosk organized by the State Ministry of Research and Technology and PDII-LIPI started in August 2000 is now growing and growing rapidly (Munaf, 2001). But it must also be recognized that the availability of telephone and electricity in certain areas of Indonesia is still limited and hence hamper the increase of Internet users. Not to mention about the unavailability of cyberlaws are clear and cyberlaws have not known tsb by the public, so this also hampers increasing investors in the field of IT Internet.

Now the government has sought to utilize and maximize the availability of information technology by forming the Office of the State Minister of Information and Technology. In each department there is even a unit that handles this information technology. In MoNE for example there is Pustekkom or Center for Technology and Communication for Education; In each University there is a Computer Center, and many other examples.

\section{CONCLUSION}

The rationale for the establishment of teacher and student colonies is the application of e-learning. This is in line with several definitions that mention that learning technology through the Internet is often 
called e-Learning or online course. Characteristics of e-Learning include: 1) Utilizing the services of electronic technology; Where teachers and students, students and fellow students or teachers and fellow teachers can communicate relatively easily without being constrained by the things that the protocol is; 2) Utilizing computer advantage ( digital media and computer networks ); 3) Using self-learning materials ( self learning materials ) stored on the computer so that it can be accessed by teachers and students anytime and anywhere if the person needs it;

The use of the Internet affects the task of teachers in the learning process. In the past, the learning process is dominated by the role of the teacher, because it is called the era of teacher.Kini, teaching and learning process, dominated by the role of teachers and books ( the era of teacher and book ) and in the future of learning and teaching process will be dominated By the role of teachers, books and technology ( the era of teacher, book and technology ).

\section{REFERENCE}

[1] Beam, P. (1997), Breaking the Sprinter's Wrist: Achieving Cost-Effectiveness in Online Learning. Paper presented at the International Symposium on Distance Education and Open Learning, organized by MONE Indonesia, IDLN, SEAMOLEC, ICDE, UNDP and UNESCO Tuban, Bali, Indonesia.

[2] Bullen, M. (2001), E-learning and the Internationalization Education, Malaysian Journal of Educational Technology 1 (1), 37-46.

[3] Elangovan, T. (1997), Internet Based Online Teaching Application with Learning Space . Paper presented at the International Symposium on Distance Education and Open Learning Organized by MONE Indonesia, IDLN, SEAMOLEC, ICDE, UNDP and UNESCO, Tuban, Bali, Indonesia, 17-20 November 1997.

[4] Hartanto, AA and Purbo, OW (2002), eLearning Technology Based on PHP and MySQL , Elex Media Komputindo, Jakarta.

[5] Hashim, Y. and Razmah. Bt. Man (2001), An Overview of Instructional Design and Development Models for Electronic Instruction and Learning, Malaysian
Journal of Educational Technology 1 (1), 1-7.

[6] Ishaq, A. (2001), On the Global Digital Divide, Finance and Development, September 2001, 44-7.

[7] Jatmiko, R. (1997), Enhancing Learning Experiences through the Use of the Internet . Paper presented at the International Symposium on Distance Education and Open Learning Organized by MONE Indonesia, IDLN, SEAMOLEC, ICDE, UNDP and UNESCO, Tuban, Bali, Indonesia, 17-20 November 1997.

[8] Mulvihill, RP (1997), Technology Application to Distance Education . Paper presented at the International Symposium on Distance Education and Open Learning Organized by MONE Indonesia, IDLN, SEAMOLEC, ICDE, UNDP and UNESCO, Tuban, Bali, Indonesia, 17-20 November 1997.

[9] Munaf, DR (2001), Cultural Threats on Development of ICT as a Tool for Open and Distance Learning. Speech delivered at the 7th International Symposium on Distance Education and Open Learning at Yogyakarta, November 2001.

[10] Soekartawi (1995), Monitoring and Evaluation of Education Project, PT Rajawali Press, Jakarta.

[11] Soekartawi (2002a). The Prospect of Learning Through the Internet . Paper presented at National Seminar on 'Technology of Education' held by UTPustekkom and IPTPI, Jakarta, 18-19 July 2002.

[12] Soekartawi (2002b), e-Learning: Concepts and Applications . Materials-Lecture delivered at Balitbang Depdiknas, Jakarta, December 18, 2002.

[13] Soekartawi (2002c), The Role of the Regional Organization for Mass Education. Invited paper presented at the International Conference on Lifelong Learning organized by Asian European Institute, Kuala Lumpur, 13-15 May 2002.

[14] Soekartawi, A. Haryono and F. Librero (2002), Greater Learning Opportunities Through Distance Education: Experiences in Indonesia and the Philippines. Southeast Asian Journal of Education(December 2002)

[15] Soekartawi, Suhardjono, T. Hartono and A. Ansjarullah (1999), Instructional Design, PT Rajawali Press, Jakarta.

[16] Sunday Star (30 June 2002), Learning in an Electronic Age . Kuala Lumpur. 
[17] Utarini, A. (1997), Process Evaluation of an Internet-Based Education on Hospital and Health Service Management at Gadjah Mada University. Paper presented at the International Symposium on Distance Education and Open Learning Organized by MONE Indonesia, IDLN,
SEAMOLEC, ICDE, UNDP and UNESCO, Tuban, Bali, Indonesia, 17-20 November 1997.

[18] Williams, B. (1999). The Internet for Teachers. IDG Books Worldwide.Inc., New York.k 